\title{
Correlation of Total Phenolic, Flavonoid and Carotenoid Content of Phyllanthus emblica Extract from Bandung with DPPH Scavenging Activities
}

\author{
Sani Nurlaela Fitriansyah*, Diah Lia Aulifa, Yessi Febriani, Emi Sapitri
}

\section{Sani Nurlaela Fitriansyah*, Diah Lia Aulifa, Yessi Febriani, Emi Sapitri}

Indonesia School of Pharmacy JI Soekarno Hatta no.354 Bandung, INDONESIA.

\section{Correspondence}

\section{Sani Nurlaela Fitriansyah}

Indonesia School of Pharmacy JI Soekarno Hatta no.354 Bandung, INDONESIA.

Phone: 022-7566484

E-mail: saninurlaela@stfi.ac.id

\section{History}

- Submission Date: 13-09-2017;

- Review completed: 05-10-2017;

- Accepted Date: 22-10-2017

DOI : 10.5530/pj.2018.3.73

Article Available online http://www.phcogj.com/v10/i3

\section{Copyright}

(c) 2018 Phcog.Net. This is an openaccess article distributed under the terms of the Creative Commons Attribution 4.0 International license.

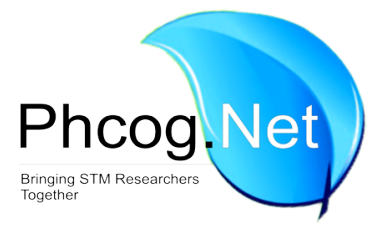

\begin{abstract}
Introduction: Many potential compounds have antioxidant activity, such as the flavonoid group, phenolics and carotenoids. Phyllanthus emblica is widespread in Bandung-Indonesia and is a very potent as an antioxidant activity. Antioxidant activity and correlation with total flavonoids, phenolics and carotenoids from Phyllantus extract from Bandung-Indonesia have not been reported. The aim of this research were to determine the antioxidant activity from extract of various parts of $P$. emblica and its correlation of antioxidant activity with the total flavonoid, phenolics and carotenoid. Method: Successive extractions of various part of Pemblica were performed by maceration using differrent polarity solvent $n$-hexane, ethyl acetate and ethanol. The antioxidant activity of each extracts was performed using DPPH (2.2-Diphenyl-1-Picrylhydrazil) method. The determination of total flavonoids, phenolics and carotenoids were performed by UV-Spectrophotometry. Antioxidant activity was demonstrated by $\mathrm{IC}_{50}$ and its correlation to total flavonoids, phenolics and carotenoids using the Pearson's method. Result: The highest antioxidant activity was given by fruit ethyl acetate (BE) extract with $I_{50} 3.032 \mu \mathrm{g} / \mathrm{mL}$. Etyl acetate extract of stem bark P.emblica (KE) had the highest of total phenol content (12.818 g GAE/100 g), ethanol extract of leaves P.emblica (DO) had the highest of total flavonoid content $(3.594 \mathrm{~g} \mathrm{QE} / 100 \mathrm{~g})$, and n-hexane extract of leave (DN) had the highest of total carotenoid content $(0.759 \mathrm{~g} \mathrm{BE} / 100 \mathrm{~g})$. Conclusion: According to coeficient correlation Pearson's between P. emblica extract with $\mathrm{IC}_{50}$ of DPPH scavengging activities, suggested that flavonoid and phenolic compound in stem bark extract and leaves extract of $P$. emblica were contributor major in its antioxidant activity with DPPH methode, and its same with carotenoid content in leaves extract of $P$. emblica.

Key words: Phyllantus emblica, Antioxidants, Flavonoids, Phenols, Crotenoids.
\end{abstract}

\section{INTRODUCTION}

Phyllanthus emblica known as Malacca is a very potent plant as an antioxidant. ${ }^{1}$ Malacca is a traditional medicinal plant that has long been used. ${ }^{2}$ Research on the biological activity of $P$. emblica has been widely performed, especially in in vitro. ${ }^{3} P$. emblica plants show a variety of biological activities, ie as anti-inflammatory, antipyretic, diuretic, and laxative, ${ }^{4}$ anticancer, ${ }^{5}$ antioxidants, antidiabetes. ${ }^{6,7}$

Chemical compunds of $P$. emblica, including fruit, stem bark, leaves, was known containt of tannins. ${ }^{1}$ In addition, chemical content of P. emblica, such as alkaloid, phenolics and flavonoids ${ }^{8}$ were also found. In one tree, there is the possibility of each part of the plant having the same chemical compounds or vice versa. Chemical compounds can be affected to biologycal activity such as antioxidant activity.

Biological activity and chemical compound in a plant can influenced by the physiological processes in a plant, environmental conditions..$^{5}$ such as sunlight condition, air pressure and temperature. ${ }^{10}$ Beside that, the maturity part of plant could be a factor to differences type and quantity secondary metabolites. ${ }^{11,12}$

Antioxidants are one of the components needed in the body, to counteract free radicals. Excessive free radicals in the human body can cause several diseases, such as diabetes, heart disease and inflammation. ${ }^{13}$ The antioxidant compounds obtained from plants may be phenolic, carotenoid. ${ }^{14,15}$ compounds, and flavonoids. ${ }^{16}$ This study was conduct the antioxidant activity of $P$. emblica extract from West Java, Indonesia, and its correlation of chemical compound in $P$. emblica extract.

\section{MATERIAL AND METHOD}

\section{Materials}

The material used are fruit simplicia, leaf and stem bark of $P$. emblica obtained from District of 
Bale Endah, Regency of Bandung, Indonesia. DPPH (2.2-diphenyl1-picrylhydrazyl) from Sigma-Aldrich (MO, USA), gallic acid from Sigma-Aldrich (MO, USA), quercetin from Sigma Aldrich (MO, USA), Beta carotene obtained from Sigma-Aldrich (MO, USA), methanol P.a, ethanol, ethyl acetate, $\mathrm{n}$-hexane and all the ingredients used in this study obtained from Merck.

\section{Sample Preparation}

Simplicia of fruit, leaf and stem bark of $P$. emblica were authenticated at Herbarium Bandungense, Faculty of Biology, Universitas Padjadjaran, Indonesia. All simplicia were sorted, washed, dried with oven at $40^{\circ} \mathrm{C}$, and ground into powder.

\section{Extraction}

Each powder simplicia was extracted using a maserator, with increasing gradient polarity solvents ( $\mathrm{n}$-hexane, ethyl acetate and ethanol). The $\mathrm{n}$-hexane extract was repeated three times. The remaining residue was extracted three times by ethyl acetate. Finally, the remaining residue was extracted three times with ethanol. So, there were nine extracts, the n-hexane extract of fruit (BN), leaf (DN) and stem bark (KN), the ethyl acetate extract of fruit (BE), leaf (DE), and stem bark (KE), the ethanol extract of fruit (BO), leaf (DO) and stem bark (KO).

\section{Phytochemical screening}

Phytochemical screening performed against all extract (BN, BE, BO, $\mathrm{DN}, \mathrm{DE}, \mathrm{DO}, \mathrm{KN}, \mathrm{KE}$, and $\mathrm{KO}$ ). $\mathrm{FeCl}_{3} 10 \%$ used for phenolic compound, amyl alcohol for flavonoid compound, gelatin for tannin, dragendorf and mayer for alkaoid, $\mathrm{KOH} 5 \%$ for quinon, vanillin $10 \%$ in $\mathrm{H}_{2} \mathrm{SO}_{4}$ for monoterpen and seskuiterpen, Lieberman-Buchard for steroid and triterpenoid. ${ }^{17}$ Saponins showed by a constant foam $\pm 10 \mathrm{~min}$ in water extracts

\section{Antioxidant activity}

The antioxidant activity were performed using DPPH (2.2-Diphenyl1-Picrylhydrazil) method, adopted from Blois (1958) $)^{18}$ with modification. Each sample was made several concentrations in P.a methanol, then into each concentration of sample solution was added DPPH $50 \mu \mathrm{g} / \mathrm{ml}$ solution in ethanol p.a (Volume 1: 1). After that, the mixture was incubated for $30 \mathrm{~min}$ in a darkened room. Then measured the absorbance of each mixture using a UV spectrophotometry. Measurements carried out three repetitions. Methanol P.a was used as a blank, DPPH $50 \mathrm{ug} / \mathrm{ml}$ solution as control, and ascorbic acid solution as a positive control. $\mathrm{IC}_{50} \mathrm{DPPH}$ was obtained from the calibration curve of the antioxidant activity of the sample on some sample concentrations in range $10 \mathrm{ppm}$ to $70 \mathrm{ppm}$.

\section{Determination of Phenolic Content}

Determination of henolic content performed by Pourmurad method. ${ }^{19}$ using Folin-ciocalteu and absorbance was measured by Spectro UVVisible at $\lambda 765 \mathrm{~nm}$. Each extract dissolve in methanol Pro analys. Galic acid solutiom used as standar of phenolic compound and to be standar curve. Linier regression equation of standar curve was used for calculating total phenolic content. Total phenolic content expressed as gallic acid equivalent per $100 \mathrm{~g}$ of extract ( $\mathrm{g} \mathrm{GAE} / 100 \mathrm{~g}$ ).

\section{Determination of total flavonoid content}

Determination of total flavonoid performed by Chang methode..$^{20}$ modification using $\mathrm{AlCl}_{3}$ and absorbance wae measured by spectro UV-Vis at $\lambda 415 \mathrm{~nm}$. Each extract dissolved in methanol Pro analysis. Quercetin solution in various concentration used as standar of flavonoid compound and to be stanadr curve. Linier regression equation of standar curve was used for calculating total flavonoid content. Total flavonoid content expressed as quercetin equivalent per $100 \mathrm{~g}$ of extract (g QE/100 g).

\section{Detrmination of total carotenoid content}

Determination of total carotenoid content performed by Thaipong methode using Spectro UV-Vis. Absorbance was measured at $\lambda 470 \mathrm{~nm}$. each extract was dissolved in n-hexane pro analysis. Beta-caroten solution in various concentration used as standar of catotenoid compound and to be standar curve. Linier regression equation of stanadar curve was used for calcualting total carotenoid content. Total carotenoid content expressed as beta-caroten equivalent per $100 \mathrm{~g}$ of extract (g BE/100 g).

\section{Statistical analysis}

Statistical analysis using ANOVA with a statistical significance level set at $p<0.05$ and post-hoc LSD procedure was done with SPSS 16 for Windows. Correlation between the total phenolic, flavonoid, carotenoid content and antioxidant acivity whiches showed with $\mathrm{IC}_{50}$ were conducted using the Pearson's method. ${ }^{16}$

\section{RESULT AND DISCUSSION}

\section{Phytochemical screening}

Phytochemical screening of extract was showed at Table 1 . The result showed their each part of P.emblica (fruit, leaf and stem bark) was affected to differences of secondary metabolite compound. Phytochemical screening was the first step to know the group of compounds contained in extracts. All extracts of $P$. emblica have flavonoids and phenolic compounds. BN, DN and $\mathrm{KN}$ do not have of phenolic compounds. Phenolics and flavonoids are compounds that can cause antioxidant activity in

Table 1: Phytochemical screening of P.emblica extract.

\begin{tabular}{|c|c|c|c|c|c|c|c|c|c|}
\hline \multirow{3}{*}{ Compound } & \multicolumn{9}{|c|}{ Result } \\
\hline & \multicolumn{3}{|c|}{ N-Hexane } & \multicolumn{3}{|c|}{ Ethyl acetate } & \multicolumn{3}{|c|}{ Ethanol } \\
\hline & DN & $\mathrm{KN}$ & BN & $\mathrm{DE}$ & KE & BE & DO & KO & BO \\
\hline Alkaloid & - & - & - & + & + & - & + & + & - \\
\hline Flavonoid & + & + & + & + & + & + & + & + & + \\
\hline Tannin and Phenol & - & - & - & + & + & + & + & + & + \\
\hline $\begin{array}{l}\text { Monoterpene and } \\
\text { Sesquiterpene }\end{array}$ & + & + & - & + & + & - & + & + & - \\
\hline Steroid & + & - & - & + & - & - & - & - & - \\
\hline Triterpenoid & - & - & - & - & - & - & + & - & - \\
\hline Quinone & - & - & - & - & - & + & + & - & + \\
\hline Saponin & - & - & - & - & - & - & + & + & - \\
\hline
\end{tabular}


extract. Flavonoids can be classified to phenolic compounds. Flavonoids which unsubstituted $\mathrm{OH}$ groups were not phenolic compounds. The presence of $\mathrm{OH}$ groups in a compound may cause increased polarity of the compound.

\section{Antioxidant activity}

Antioxidant activity expressed as $\mathrm{IC}_{50}$ value. The result showed, $\mathrm{BE}$ had the smallest $\mathrm{IC}_{50}$ value than another extract, whereas $\mathrm{DE}$ had the highest $\mathrm{IC}_{50}$ value than another extract. $\mathrm{IC}_{50}$ value of each extract showed at Figure 1. Antioxidant activity of $P$. emblica fruit and leaf extracts has been reported. ${ }^{22,23}$ Many reported, antioxidant activity from fruit, leaf and stem bark extracts of $P$. emblica using a solvent with increased polarity (n-hexane, ethyl acetate and ethanol) and antioxidant activity of the stem bark P.emblica. The most commonly used method of determining antioxidant activity is the DPPH method because it is a relatively stable and sensitive free radical in determining antioxidant activity. ${ }^{15}$ The DPPH method is based on the ability of the antioxidant compounds of the extract to absorb DPPH free radicals shown visibly with a more faded DPPH coloring. ${ }^{23}$ The more faded color of DPPH solution, the more $\mathrm{DPPH}$ is suppressed by the antioxidant compounds of the extract.

Antioxidant activity of extract were showed with $\mathrm{IC}_{50}$ value. $\mathrm{IC}_{50}$ value of DPPH scavengging activities was contrasdictinction with percentage of DPPH scavengging activities. It's means, the highest antioxidant activity was indicated by the lowest value of $\mathrm{IC}_{50} . \mathrm{IC}_{50}$ value of P.emblica extract were variated. The environmental conditions. ${ }^{5}$ such as sunlight condition, ${ }^{10}$ the marurity part of plant and differences part of plant could be a factor to differences type and quantity secondary metabolites. ${ }^{11,12}$ The differences and quantity of secondary metabolites of medicinal plant could be causes differences biologycal activity. ${ }^{24} \mathrm{BE}$ was the lowest $\mathrm{IC}_{50}$ value in fruit extract P.emblica, $\mathrm{DN}$ was the lowest $\mathrm{IC}_{50}$ value in leaf extract of P.emblica, and $\mathrm{KO}$ wa the lowest $\mathrm{IC}_{50}$ in stem bark extract of P.emblica. BE was the lowest whereas comared to all extract of P.emblica. The result indicated, BE was the highest antioxidant activity compared to all extract of P.emblica.

Previous study, ${ }^{22}$ stated methanol-water extract of leaf P.emblica have $40.24 \mu \mathrm{g} / \mathrm{ml}$ of $\mathrm{IC}_{50}$ value. D.sumalatha. ${ }^{23}$ showed antioxidant activity was $71.75 \%$ at $125 \mu \mathrm{g} / \mathrm{ml}$ ethanol of combine leaf and fruit extract P.emblica. Suaib, ${ }^{4}$ stated ethanol of fruit extract P.emblica had the higher than a water extract of fruit P.emblica. $\mathrm{IC}_{50}$ of extract P.emblica was compared to ascorbic acid of $\mathrm{IC}_{50}$ value. $\mathrm{IC}_{50}$ value of ascorbic acid was $2.87 \mu \mathrm{g} / \mathrm{ml}$. This result means, antioxidant activity of ascorbic acid had a higher than

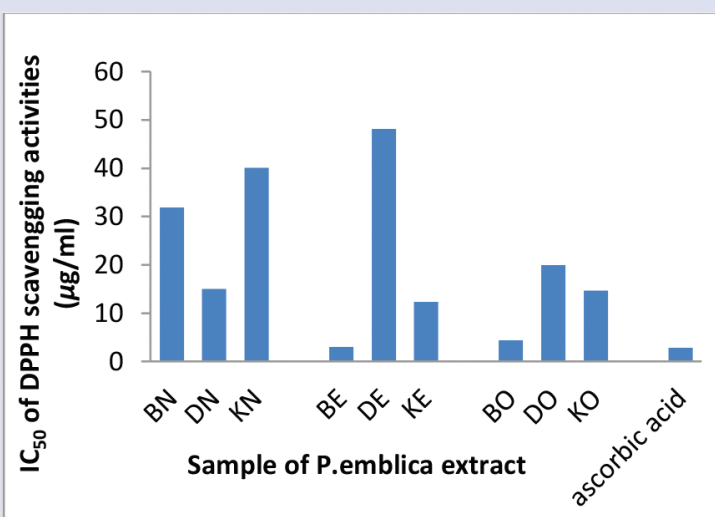

Figure 1: $I C_{50}$ of DPPH scavengging activities of P.emblica extract.

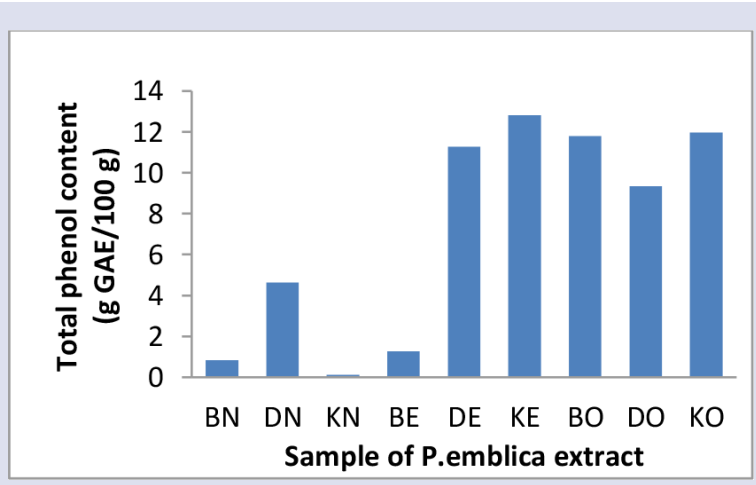

Figure 2: Total Phenol content of P.emblica extract.

antioxidant activity of extract P.emblica. This result indicated linier with previous research of Suaib, ${ }^{4}$ that antioxidant activity ethanol and water extract of fruit P.emblica had a lower than antioxidant activity of ascorbic acid.

According to Blois, ${ }^{12}$ potency antioxidant activity of the sample can be categoried to very strong antioxidant which had $\mathrm{IC}_{50}$ lower than $50 \mu \mathrm{g} / \mathrm{ml}$ and wich had higher than $50 \mu \mathrm{g} / \mathrm{ml}$ was a weak antioxdant activity. Antioxidant activity of all extract P.emblica from Bandung-Indonesia had $\mathrm{IC}_{50}$ lower than $50 \mu \mathrm{g} / \mathrm{ml}$ and caould be categoried to very strong antioxidant activity. Antioxidant activity of samples may be suspected containing the compound capable donating proton on free radicals. ${ }^{25}$ Flavonoid and phenol were compound capable donating proton on free radicals. Besides that, cinamic acid and benzoic acid were compound capable donating proton on free radicals. ${ }^{26,27}$ Cinamic acid more higher contributor as antioxidan activity than benzoic acid. ${ }^{26,27}$

\section{Total phenol content}

Total phenol conten in $\mathrm{BN}, \mathrm{BE}, \mathrm{BO}, \mathrm{DN}, \mathrm{DE}, \mathrm{DO}, \mathrm{KN}, \mathrm{KE}$, and $\mathrm{KO}$ varied from 0.110 to $12.818 \mathrm{~g} \mathrm{GAE} / 100 \mathrm{~g}$, and can be seen in Figure 2 . Linier regression equation of gallic acid standard curve is $\mathrm{y}=0.0449+$ $0.1836, \mathrm{R}^{2}=0.996$.

Determination total phenolic of P.emblica extract varied from $0.110 \mathrm{~g}$ GAE/100 g to $12.818 \mathrm{~g}$ GAE/100 g. Phenolic compound as major compound in medicinal plant and were caused many biology activity. ${ }^{28}$ Phenol is very potent as antioxidant compound. ${ }^{29}$ Determinaton of total phenol content was by Folin-ciocalteu reaction. ${ }^{19}$ Total phenol content was calculation by galic acid standard curve were $y=0.044 x+0.185$; $\mathrm{R}^{2}=0.996$ and expressed as gallic acid. KE was had the highest of total phenol were $12.818 \mathrm{~g} \mathrm{GAE} / 100 \mathrm{~g}$. According previous research, Luqman, ${ }^{4}$ stated total phenol of water and ethanol extract fruit P.emblica were 336 \pm 33.94 and $318 \pm 45.25 \mu \mathrm{g} \mathrm{GAE} / \mathrm{mg}$. Acoording to Naik, ${ }^{30}$ total pheno $\mathrm{f}$ water extract fruit P.emblica was 33\% equivalent to gallic acid.

\section{Total flavonoid content}

Total flavonoid conten in BN, BE, BO, DN, DE, DO, KN, KE, and KO varied from 0.038 to $3.594 \mathrm{~g} \mathrm{QE} / 100 \mathrm{~g}$, adn can be seen in Figure 3 . Regression linier equation of gallic acid standar curve is $\mathrm{y}=0.0342 \mathrm{x}+$ $0.0857, \mathrm{R}^{2}=0.991$.

Determination of total flavonoid in. P.emblica extract varied at $0.038 \mathrm{~g}$ $\mathrm{QE} / 100 \mathrm{~g}$ sampai 2,982 g QE/100 g. This result means, part of P.emblica plant has production flavonoid in differences quantity. Determination total flavonoid used $\mathrm{AlCl}_{3}$ reaction. ${ }^{20}$ Total flavonoid content at P.emblica extract calculation by standard curve $y=0.0342+0.0857 ; \mathrm{r}^{2}=0.991$ and expressed as quercetin. $\mathrm{AlCl}_{3}$ will form omplex with $\mathrm{OH}$ functional in 


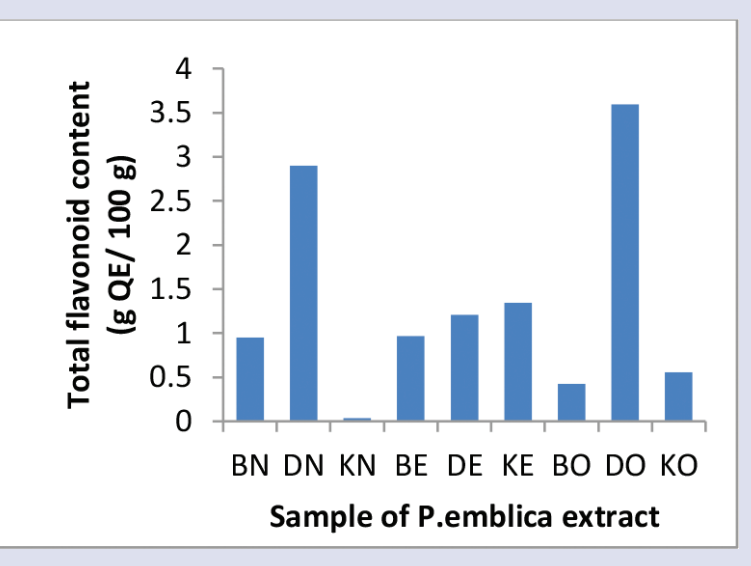

Figure 3: Total flavonoid content of P.emblica extract.

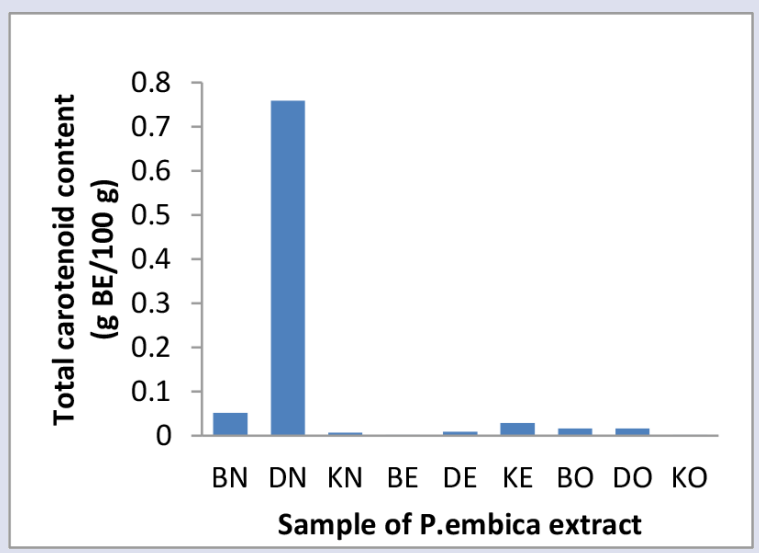

Figure 4: Total carotenoid content of P.emblica extract.

C-3, 4 oxo, C-5 and or ortho group in $\mathrm{C} 3^{\prime}-\mathrm{C} 4{ }^{\prime 31} \mathrm{OH}$ functional flavonoid in C-3, and or C-5 and ortho position in C3'-C4' could be as antioxidant activity. ${ }^{31}$ In previous study, Dhale, ${ }^{32}$ stated ethanol extract of fruit and leaf P.emblica have a flavonoid compound. Hasan, ${ }^{33}$ stated P.embica herba have flavonoid compound as quercetin and luteolin. According to Ghosal, ${ }^{34}$ fruit of P.emblica extract has flavonoid compound as rutin. $\mathrm{OH}$ functional at quercetin, luteolin and rutin could be form complex with $\mathrm{AlCl}_{3}$. BE had the highest of total flavonoid in fruit extract of P.emblica as $0.967 \mathrm{~g} \mathrm{QE} / 100 \mathrm{~g}$. DO had the highest of total flavonoid in leaf extract P.emblica as $3.594 \mathrm{~g} \mathrm{QE} / 100 \mathrm{~g}$. Whereas in stem bark extract of P.emblica, $\mathrm{KE}$ wa the highest of total flavonoid as $1.347 \mathrm{QE} / 100 \mathrm{~g}$. KN had the lowest of total flavonoid wich compared to all extract of P.emblica from Bandung-Indonesia as $0.038 \mathrm{~g} \mathrm{QE} / 100 \mathrm{~g}$.

\section{Total carotenoid content}

Total carotenoid conten in BN, BE, BO, DN, DE, DO, KN, KE, and KO varied 0.0004 to $0.7588 \mathrm{~g} \mathrm{BE} / 100 \mathrm{~g}$ and can be seen in Figure 4. regression linier equation of beta caroten standar curve is $\mathrm{y}=0.1061 \mathrm{x}+0.0008$, $\mathrm{R}^{2}=0.998$.

Determination of total carotenoid content at extract P.emblica varied under $1 \mathrm{~g} \mathrm{BE} / 100 \mathrm{~g}$. This result means, carotenoid compound in P.emblica extract as fruit, leaf and stem bark were lower production than phenol and flavonoid. Strong yellow to orange was a color of carotenoid compound. That color was caused by double bond conjugated in carotenod compound. DN was more strong yellow to orange color than $\mathrm{BN}, \mathrm{BE}$, $\mathrm{BO}, \mathrm{DE}, \mathrm{DO}, \mathrm{KN}, \mathrm{KE}$, and KO. Total carotenoid content at P.emblica extract calculation used standard curve, $y=0.105 x+0.0008 ; R^{2}=0.9983$ and expressed as $\beta$-caroten. Carotenoid compound were inclanation non polar to young shoot polar caracter. Becaused that, all of P.emblica extract (BN, BE, BO, DN, DE, DO, KN, KE dan $\mathrm{KO}$ ) soluted in n-hexane solution. BN had the highest of ttoal carotenoid in fruit extract of P.emblica as $0.052 \mathrm{~g} \mathrm{BE} / 100 \mathrm{~g}$, DN had the highest in leaf extract of P.embica as $0.759 \mathrm{~g} \mathrm{BE} / 100 \mathrm{~g}$ and $\mathrm{KE}$ had the highest in stem bark extract of P.emblica as $0.029 \mathrm{~g} \mathrm{BE} / 100 \mathrm{~g}$. KO had the lowest of total carotenoid content were compared to all extract P.emblica as $0.0004 \mathrm{~g} \mathrm{BE} / 100 \mathrm{~g}$. So far, have not been reported about total carotenoid content in P.emblica extract.

\section{Correlation between antioxidant activity with total phenol, total flavonoid and total carotenoid of P.emblica extract}

Correlation between total phenol, flavonoid and carotenoid with $\mathrm{IC}_{50}$ of DPPH scavengging activities was expressed with Pearson correlation coeficient (r) and showed in Table 2. Pearson correaltion coefficient of total phenolic, flavonoid, carotenoid content of fruit P.embilca extract with $\mathrm{IC}_{50}$ of DPPH scavengging activities were $\mathrm{r}=-0.492, \mathrm{p}<0.179$; $\mathrm{r}=0.510, \mathrm{p}<0.161 ; \mathrm{r}=0.973, \mathrm{p}<0.01$. Pearson correaltion coefficient of total phenolic, flavonoid, carotenoid content of leaf Phyllantus embilca extract with $\mathrm{IC}_{50}$ of DPPH scavengging activities were $\mathrm{r}=0.813, \mathrm{p}<0.001$; $\mathrm{r}=-0.926, \mathrm{p}<0.01 ; \mathrm{r}=-0.621, \mathrm{p}<0.74$. While in stem bark of P.emblica extract were $\mathrm{r}=-1.00, \mathrm{p}<0.01 ; \mathrm{r}=-0.843, \mathrm{p}<0.01 ; \mathrm{r}=-0,368, \mathrm{p}<0.329$.

Total phenol, flavonoid and carotenoid of P.emblica extract correlation with $\mathrm{IC}_{50}$ value of scavengging DPPH used Pearson method and expressed as Pearson correlation (r). According to Fidrianny, ${ }^{25}$ if $(\mathrm{r})$ value $=0.61 \leq$ $\mathrm{r} \leq 0.97$, that means positive and high correlation, and if $\mathrm{r}=-0.61 \leq$ $\mathrm{r} \leq-0.97$, that means negative and high correlation. Negative and high correlation it was showed correlation between total phenol, flavonoid and carotenoid compound with $\mathrm{IC}_{50}$ of scavengging DPPH. This result means, the greater of total phenol, flavonoid and carotenod content was indicated the smaller value $\mathrm{IC}_{50}$ of $\mathrm{DPPH}$ scavengging activities.

Stem bark extract of P.emblica had negative and high correlation to total phenol conten $(\mathrm{r}=-1.00 ; \mathrm{p}<0,01)$. This result means, phenolic compound in stem bark extrac of P.emblica has a mayor group wiches suspected antioxidant activity. Phenolic compound in fruit and leaf extract of P.emblica have not been mayor group compound wiches suspected antioxidant activity. Phenolic compound in fruit extract of P.embica more been play role to antioxidant actvity than phenolic compound in leaf extract of P.emblica.

Table 2 : Pearson's correlation of total phenol, flavonoid and carotenoid content with extract of P.emblica.

\begin{tabular}{cccc}
\hline \multirow{2}{*}{ IC $\mathrm{F}_{50}$ of DPPH Scavengging } & \multicolumn{3}{c}{ Pearson' Correlation } \\
\cline { 2 - 4 } & Total Phenol Content & Total Flavonoid Content & Total Carotenoid Content \\
\hline $\mathrm{IC}_{50}$ of Fruit Extract & -0.492 & 0.510 & 0.973 \\
$\mathrm{IC}_{50}$ of Leaf Extract & 0.813 & -0.926 & -0.621 \\
$\mathrm{IC}_{50}$ of Stem Bark Extract & -1.00 & -0.843 & -0.368 \\
\hline
\end{tabular}


Leaf and stem bark extract of P.embica had negative and high correlation to total flavonoid content as $(\mathrm{r}=-0.926 ; \mathrm{p}<0.01, \mathrm{r}=-0.843 ; \mathrm{p}<0.01)$. This result means, the greater of total flavonoid content was indicated the smaller value $\mathrm{IC}_{50}$ of DPPH scavengging activities. Flavonoid compound in leaf and stem bark extract of P.emblica was a mayor group compound wich suspected to antioxidant activity. $\mathrm{OH}$ functional in flavonoid compound can suspected antioxidant activity. $\mathrm{OH}$ functional at $\mathrm{C}-3^{25}$ and ortho position at C-3' and C-4' will increased antioxidant activity. ${ }^{26}$ Ortho $\mathrm{OH}$ position at C-3' and C-4' will more increase antioxidant potency than $\mathrm{OH}$ functional at $\mathrm{C}-3$. Besides that, oxo group at $\mathrm{C}-4^{26}$ and double bond between C-2 and C-3 can be a high suspected to antioxidant activity. ${ }^{13,25}$ This result means, flavonoid compound in leaf and stem bark wiches increased antoxidant activity were has $\mathrm{OH}$ functional at $\mathrm{C}-3$, ortho positon at C-3' and C-4', or has oxo functional at C-4. So far, study of correlation stem bark extract of P.emblica to total flavonoid content used Pearson correlation have not been reported.

Determination correlation between total carotenoid content to $\mathrm{IC}_{50}$ of DPPH scavengging activities have showed carotenoid compound were not been mayor group as antioxidant activity contributor compound. Leaf extract of P.emblica had the highest as contributor antoxidant compound than stem bark extract and fruit extract. Pearson correlation of leaf extract as $r=-0.621 ; p>0.05$. Carotenoid compound as beta-carotene and $\alpha$-tocopherol was the high suspected to antioxidant potency. ${ }^{35,56}$ $\beta$-carotene was efective as antioxidant compound in human body. ${ }^{35,36}$ Much of double bond conjugated in $\beta$-carotene, suspected to antoxidant activity. ${ }^{35,37,38}$ Besides that, zeaxanthin, astaxanthin and astxanthin$\beta$-glucoside ${ }^{35,36}$ can suspected to antioxidant activity. The previous study, so far have not been reported about correlation total carotenoid content with $\mathrm{IC}_{50}$ value of DPPH scavengging activities sed Pearson's correlation. Becaused that, this result not yet compared to previous study.

\section{CONCLUSION}

Fruit extract of P.emblica had the highest antioxidant activity than leaf extrcat and stem bark extract. Phenol compound in stem bark extract of P.emblica had the highest as contributor antioxidant compound than in leaf and fruit extract. Flavonoid and carotenoid compound in leaf extract of P.emblica had the highest as contributor antioxidant compound than in fruit extract and stem bark extract of P.emblica.

\section{ACKNOWLEDGEMENT}

We would like to thank Sekolah Tinggi Farmasi Indonesia (Yayasan Hazanah) for funding and supporting this research.

\section{CONFLICT OF INTEREST}

The author declare that there is no conflict of interest, financial or otherwise regarding the publication of this paper.

\section{ABBREVIATIONS USED}

DPPH: 2.2-Diphenyl- 1-Picrylhydrazil.

\section{REFERENCES}

1. Charoenteerabon J, Ngamkitidechakul C, Soonthornchareonnon, Jaijoya K, Sireeratawon S. Anttioxidant activities of the standardized water extract from fruit of Phyllantus emblica Linn. Songklanakarin J Sci Technol. 2010;32(6):599-604.

2. Khan KH. Roles of Emblica officinalis in Medicine - A review. Bot. Res. International. 2009;2(4):218-28.

3. Saeed S, Tariq P. Antibacterial activitie of Emblica officinalis and Coriandrum sativum against $G$ negative urinary pathogens. Pak. J. Pharm. Sci. 2007;20(1):32-5.

4. Luqman S, Kumar R. Correlation between scavenging property and antioxidant activity in the extracts of Emblica officinalis Gaertn., syn. Phyllanthus emblica L. Fruit. Annal of Phytomedicine. 2012;1(1):54-61.

5. Ngamkitidechakul CK, Jaijoy P, Hansakul N. Soonthornchaeonnon and Sireera- tawong, S. Antitumor effects of Phyllantus emblica L.: Induction of cancer cell apoptosis and Inhibition of in vio tumour promotion and in vitro invasion of human cancer cells. Phytother Res. 2010;24(9):1405-13.

6. Nampoothiri SV, Prathapan A, Cherian OL, Raghu KG, Venugopalan VV, Sundaresan A. In vitro antioxidant and inhibitory potential of Terminalia bellerica and Emblica officinallis fruit against LDL oxidation and key enzymes linked to type 2 diabetes. Food Chem. Toxicol. 2011;49(1):125-31.

7. Hazra B, Sarkar R, Biswas S, Mandal N. Comparative study of the antioxidant and reactive oxygen species scavenging properties in the extract of the fruit of Terminalia chebula, Terminalia belerica and Emblica officinalis. BMC Complement Altern Med. 2010;10(1):20.

8. Chatterjee A, Chattopadhyay S, Bandyopadhyay SK. Biphasic effect of Phyllantus emblica L. Extract on NSAID-Induced Ulcer: An antioxidant trail Weaved with immunomodulatory effect. Evid. Based Complement. Alternat. Med, Articel ID 146808. 2011.13.

9. Dai J, Mumper RJ. Plant phenolic extracton, analysis and their antioxidant and anticancer properties. Molecule. 2010;15(10):7313-52.

10. Ghasemzadeh A, Nasiri A, Jaafar HZ, Baghdadi A, Ahmad I. Changes in phytochemical synthesis, chalcone synthase activity and pharmaceutical qualities of Sababh snake grass (Clinacanthus nutans L.) in relationship to plant age. Molecules. 2014;19(11):32-48.

11. Wang SY, Bunce JA, Mass J. Elevated carbon dioxide increases content of antioxidant compounds in field-grown strawberries. J Agric Food Chem. 2003;51(15):4315-20.

12. Duma Y, Dadomo M, Di Lucca G, Grolier P. Effects of environmental factors and agricultural techniques on antioxidantcontent of toamoes. J Sci Food Agric. 2003;83(5):369-82.

13. Adekunle AS, Aline AB, Afolabi OK, Rocha JBT. Determination of free phenolic flavonoid contents and antioxidant capacity of ethanolic extracts obtained from leaves of mistletoe (Tapinanthus globiferus). Asian J Pharm Clin Res. 2012;5(3):36-41.

14. Duh PD, Tu YY, Yen GC. Antioxidants activity of aqueous extract of Hamiyut (Chrysanthemum morifolium Ramat). Lebensmwiss Technol. 1999;32(5):269-77.

15. Verru P, Kishor MP, Meenakshi M. Screening of medicinal plant extracts for antioxidant activity. J Med Plant Res. 2009;3(8):608-12.

16. Fidrianny I, Puspitasari N, Singgih M. Antioxidant activities, total flavonoid, phenolic, carotenoid of various shells extract from four species of legumes. Asian J Pharm Sci. 2014;7(4):42-6.

17. Marliana SD, Suryanti $V$, Suyono. Skrining fitokimia dan analisis kromatografi lapis tipis komponen kimia buah labu siam (Sechium edule Jacq. Swartz.) dalam ekstrak etanol. Biofarmasi. 2005;3(1):26-31.

18. Blois MS. Antioxidant determination by the use of stable free radical. Nature. 1958;181(4617):1199-200.

19. Pourmorad F, Hosseinimehr SJ, Shahabimajd N. Antioxidant activity, phenol and flavanoid content of some selected iranian medicinal plants. Afr J Biotechnol. 2006; 5(11):1142-5.

20. Chang CC, Yang MH, Wen HM, Chern JC. Estimation of total flavonoid content in propolis by two complementary colorimetric methods. J Food Drug Anal. 2002;10(3):178-82.

21. Thaipong K, Boonprakob U, Crosby K, Zevallos LC, Byrne DH. Comparison of ABTS, DPPH, FRAP, and ORAC assay for estimating antioxidant activity from guava fruit extracts. J Food Comp Anal. 2006;19(6):669-75.

22. Nain P, Saini V, Sharma S. In-vitro antibacterial and antioxidant activity of Emblica officinalis leave extract. Int J Pharm Pharm Sci. 2012;4(1):385-9.

23. Sumalatha D. Antioxidant and antitumor activity of Phyllantus emblica. Int J Curr Microbiol App Sci. 2013;2(5):189-95

24. Ghasemazadeh A, Jaafar HZ, Ashkani S, Rahmat A, Juraimi AS, Puteh A, et al. Variation in secondary metabolite production as well as antioxidant and antibacterial activities of Zingiber zerumbet (L.) at different stages of growth. BMC Complementary and Alternative Mediccine. 2016;16(1):104.

25. Fidrianny I, Aristya T, Hartati R. Antioxidant capacities of various leaves extracts from three species of legumes and correlation with total flavonoid, phenolic, carotenoid content. Int J Pharmacogn Phytochem Res. 2015;7(3):628-34.

26. Fidrianny I, Darmawati A, Sukrasno. Antioxidant capacities from different polarities extracts of Cucurbitaceae leaves using FRAP, DPPH assay and correlation with phenolic, flavonoid, carotenoid content. Int J Pharm Pharm Sci. 2014;6(2):858-62

27. Heim KE, Tagliaferro AR, Bobilya DJ. Flavonoid antioxidants: chemistry, metabolism and structure-activity relationship. J Nutr Biochem. 2002;13(10):572-84.

28. Ani V, Naidu KA. Antioxidant potential of bitter cumin (Centratherum anthelminticum (L) Kuntze) seed in vitro models. BMC Complement. Altern Med. 2011.11(1):40

29. Povichi N, Phrutivorapongkul A, Suttajit M, Chaiysur C, Leelapompisid P. Phenolic content and in vitro inhibitory affects on antioxidant and protein gycation of some Thai medicinal plant. Ak. J. Pharm. Sci. 2010.23(4):403-8.

30. Naik GH, Priyadarsini KI, Bhagirathi RG, Mishra B, Mishra KP, Banavalikar MM et al. In vitro antioxidant stidies and free radical reactions of triphala, an ayurvedic formulation and its constituents. Phytotherapy Research. 2005;19(7):582-6. 
31. Kalpana B, Vijay DW, Sanjay ST, Bhushan RS. Phytochemical, antimicrobial evaluation and determination of total phenolic and flavonoid contents of Sesbania grandiflora flower extract. Int J Pharm Pharm Sci. 2012;4(4):229-32.

32. Dhale DA, Mogle UP. Phytochemical screening and antibacterial activity of Phyllantus emblica (L). Science Research Reporter. 2011;1(3):138-42.

33. Hasan R, Islam N, Islam R. Phytochemistry, pharmacological activities and traditional uses of Emblica officinalis : A review. Int. curr. pharm. J. 2016;5(2):14-21.

34. Ghosal S, Tripathi VK, Chouhan S. Active constituents of Emblica officinalis. Part I. The chemistry and antioxidant effest of two new hydrolysable tannins, emblicanin A and B. Indian Journal of chemistry. 1996;35(1):941-8.

35. Britton G, Liaaen-Jensen S, Pfander H. Carotenoids. Handboook, Birkhauser Verlag Basel: Switzerland. 2004

36. Fiedor J, Burda K. Potential role of carotenoids as antioxidant in human health and disease. Nutrients 2014;6(2):466-88.

37. Krinsky NI. The biological properties of carotenoids. Pure Appl Chem. 1994;66(5):1003-10.

38. Dutta D, Utpai CR, Runu C. Structure, health benefits, antioxidant property and processing and storage of carotenoids. Afr J. Biotechnol. 2005;4(13):1510-20.

\section{GRAPHICAL ABSTRACT}

\section{Phyllantus emblica}

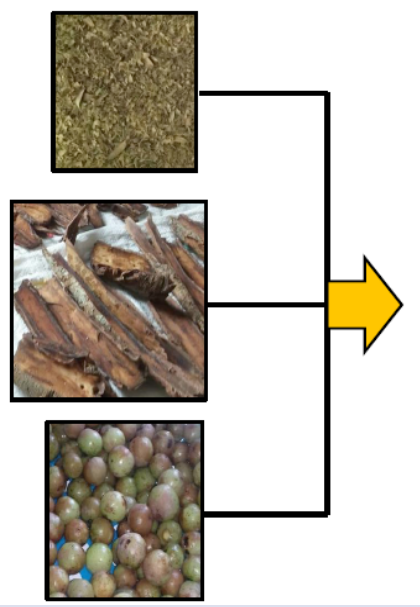

\section{ABOUT AUTHORS}

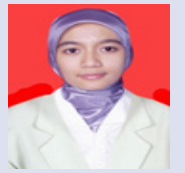

Sani Nurlaela Fitriansyah: Is a lecturer in Sekolah Tinggi Farmasi Indonesia (Indonesian School of Pharmacy), Indonesia, in Pharmaceutical Biology Department. Specialization: Pharmacognosy and Natural Product Standardization.

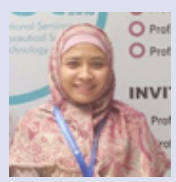

Diah Lia Aulifa: Is a lecturer in Sekolah Tinggi Farmasi Indonesia (Indonesian School of Pharmacy), Indonesia, in Pharmaceutical Biology Department. Develop work in Phytochemistry and Phytoteraphy from plants.

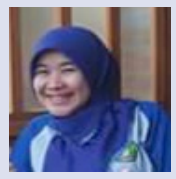

Yessi Febriani: Is a lecturer in Sekolah Tinggi Farmasi Indonesia (Indonesian School of Pharmacy), Indonesia, in Pharmaceutical Biology Department, in the area concentration Phytochemistry and Pharmacognosy.

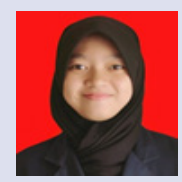

Emi Sapitri: Is an undergraduate student of the Pharmacy Course, Sekolah Tinggi Farmasi Indonesia (Indonesian School of Pharmacy), Indonesia.

Cite this article: Fitriansyah SN, Aulifa DL, Febriani Y, Sapitri E. Correlation of Total Phenolic, Flavonoid and Carotenoid Content of Phyllanthus emblica Extract from Bandung with DPPH Scavenging Activties. Pharmacog J. 2018;10(3):447-52. 